\title{
DNA Fragmentation
}

National Cancer Institute

\section{Source}

National Cancer Institute. DNA Fragmentation. NCI Thesaurus. Code C107432.

A process that results in the breaking of macromolecular DNA into small pieces. 